\title{
The Impact of Shadowing Technique on Tertiary EFL Learners' Listening Skill Achievements
}

\author{
Sumarsih $^{1}$ \\ ${ }^{1}$ English and Literature Department, Faculty of Languages and Arts, Universitas Negeri Medan, Indonesia \\ Correspondence: M. Pd. Sumarsih, English and Literature Department, Faculty of Languages and Arts, \\ Universitas Negeri Medan, Medan, Indonesia. Tel: 62-812-604-7395. E-mail: isih58@yahoo.com
}

Received: June 2, 2017 Accepted: July 3, 2017 Online Published: July 26, 2017

doi:10.5539/ijel.v7n5p184 URL: http://doi.org/10.5539/ijel.v7n5p184

\begin{abstract}
This paper is aimed at describing the impact of Shadowing Technique on students' listening skills achievement. Therefore, the experimental research was conducted and the techniques on collecting the data were administrating pre- and post- tests to the experiment and control groups, which consisted of 30 university students in each group. Then, t-test and ANCOVA were applied on analyzing the data, then to find the impact of shadowing technique on EFL learners' listening skill achievements in English Department of Universitas Negeri Medan (UNIMED), Indonesia. As a result, there was a significant difference between the mean of experimental and control groups $(F=8.98, p=.004<.05)$. In addition, there was a significant effect of applying shadowing technique on students' listening skill achievements $(F=56.10, p=0.00<0.05)$ and the experimental group grammatically outperformed the control group. In conclusion, the null hypothesis was rejected and the alternative hypothesis was accepted.
\end{abstract}

Keywords: shadowing, listening skill, Tertiary Students, and ESL

\section{Introduction}

In teaching and learning English, there are four skills, which should be mastered by learners namely listening, speaking, reading and writing. Furthermore, among all those skills, listening skill is the most essential skill in learning English because listening is the first stage in acquiring and learning language before speaking, reading or writing. Therefore, listening is the bridge to master the three other skills. In line with this, Sevik (2012) stated that pupils in learning English will first listen, talk, read, and then write. Beside that, listening skill is the fundamental part to develop other skills in foreign or second language learning (Ghanbari \& Hashemian, 2014).

English Department of Universitas Negeri Medan (UNIMED) allocates Listening Skill subject started from the first up to the fourth semester. Basically, the main objective of listening skill is to develop the students' comprehension and understanding accurately to what the English speaker says. Generally, most students of English as foreign language such as in Indonesia tend to avoid Listening skill subject because of its difficultness. Schmidt (2016) found in his study that listening skill is the most difficult skill for a foreign language learner. Then specifically, related to the preliminary data, which were collected on January 2017, it can be summarized that $80 \%$ of the students' listening skill score were still under the passing grade which is 70 over 100 . Consequently, the students need to retake this subject.

Literally, teaching and learning English is a complicated task to do. The lecturer needs to find the suitable method to the students' needs and context. Many agree with Brown (2007) who said that there is no a single best method in teaching language, therefore, we, as lecturers or teachers, should find the relevant method to the students' needs and context. In fact, previous teaching listening technique applied in tertiary level has shown that there was no significant improvement on students' listening skills. Then, they are expected to be an English teacher after graduation while their abilities in English particularly in listening comprehension were still far from what being expected. Thus, it is very crucial to help the lecturer to give a positive impact on the students' achievement in listening skill. Therefore, this study proposed an alternative to this condition, which was applying shadowing technique in teaching and learning of English as foreign language in English Department UNIMED.

Shadowing has become an interesting topic in English language teaching and learning field until now. Basically, 
according to Tamai (2002), shadowing is a listening exercise in which the English learners track the heard speech and repeat it as exactly as possible while listening attentively to the incoming information. In addition, Tanaka (2004) pointed out that shadowing leads learner to reproduce the heard speech within a short time. She said that through this exercise, the learners' listening comprehension (receptive skill) and reproduction skill are highlighted. Accordingly, this method should be appropriate to the students of English in English Department UNIMED.

The main study objective was to examine whether shadowing could give a positive impact to the achievement of English tertiary learners who were in the first semester of English Department UNIMED. Meanwhile, the specific objectives of this study were to 1) find the mean of learners' listening score before and after applying shadowing technique, 2) examine the significant difference of the learners' listening scores between learners taught through shadowing technique and classical method, and 3) examine the significant effect of shadowing technique on the learners' achievements of listening skill in tertiary level.

\section{Literature Review}

\subsection{Shadowing}

According to Shiki et al. (2010), shadowing technique can be defined as a prompt process of verbal expression repetition, while repeating is an off-line task since it supplies learners with silent pauses to make the sounds. In addition, Kadota (2007) stated that the repetition process incoming speech and controlling the shadowed material occupies many areas of the learners' brains, particularly the center of language. Nevertheless, shadowing technique actually is cognitive and active activities where the learners trail the heard speech and clearly verbalize it while listening continuously (Tamai, 1997).

Furthermore, the benefits of the shadowing technique are: firstly, activating the process of bottom-up and top-down (Tamai, 1992), secondly, echoic memory is operated to maintain the incoming sounds information more precisely (Kadota, 2007). Students are able to spend more time on analyzing the new information. Additionally, Someya (1996) said that shadowing technique assists to enhance the sense of prosody: the rhythm, intonation, and accent of speech. Prosody is the important element in communication because up to $40 \%$ of communication meaning is captured by prosody.

Practically, shadowing technique has been used in Japan in language teaching context. Such as Murphey (2001), Takizawa (2002) Kadota \& Tamai (2005) elaborate the varieties in ESL/EFL teaching context. Therefore, Takizawa's model was applied to this study because in his model there are interpretation activities. According to researcher, this type of the shadowing technique is appropriate to Indonesian EFL teaching context because Hamada (2011) warned that many students believe that they have to translate every words they hear immediately, which effects to decrease self-efficacy through translation failure. Then, to make students feel challenged in practicing shadowing technique, the other activities like translation; silent reading and simply listening are highly recommended (Shiki et al., 2010). It means that relaying shadowing technique solely would not improve the learners' achievements in listening skill. Thus, this study followed the instruction recommended by Takizawa (2002). Below is the shadowing instruction from Takizawa (2002):

Table 1. Takizawa's shadowing instructions (2002)

\begin{tabular}{ll}
\hline Procedures & Activities \\
\hline Listening to audio & Learners should only listen without reading a text. \\
Slash Reading & $\begin{array}{l}\text { Learners should read the text by slashing, comprehending the text by chunks, and } \\
\text { checking the unknown (meaning) words in the text. }\end{array}$ \\
Shadowing & Learners should practice repeatedly till reproducing $70 \%$ to $80 \%$ of the text. \\
Repeating and Shadowing & Learners should listening to the audio and shadow after that \\
Translation & Student should translate the text slash by slash \\
Reproduction & Student should repeat the audio pause by pause \\
Translation & Students should translate the text, pause by pause \\
Delayed shadowing & Students should shadow by 3 (three) or 4 (four) words \\
Content Shadowing & Students should shadow and think about the meaning \\
Translating while listening & Students should listen and translate the text simultaneously. \\
\hline
\end{tabular}

\subsection{Previous Studies of Shadowing Technique in Listening Skill}

Takizawa (2002) asserted that the shadowing technique is an effective technique to improve bottom-up process 
in listening skill, instruct to acquire more successful listening comprehension. Moreover, learners rise to improve pronunciation, get more focus, and get used to natural speed as well. Therefore, students can receive many benefits and listening skills improvement from shadowing way.

Factually, the effectiveness of shadowing technique has been examined in classroom research. The study was conducted to 112 students on showing the effective and practical techniques to implement shadowing in the classroom by using textbook (Suzuki, 2007). In addition, Tamai (2005) did an experimental research into 45 learners in each group of two. It was assumed that shadowing helps weak students. He divided each group of 45 students into three different levels. After 13 lessons, the result of the shadowing groups presented that the weak and the average students had significant enhancement. Besides that, Onaha (2004) taught 43 tertiary learners through shadowing technique and dictation and concluded that the combination of the exercises had effectively improved the learners' listening comprehension skills.

Theoretically and practically in Japan, the shadowing technique has given many proofs in EFL context that it could improve the students' achievement in listening comprehension skills. Therefore, this technique must be used in teaching listening skill in Indonesia since Indonesian also recognizes English as a Foreign Language (EFL).

\subsection{Hypothesis}

In accordance with the literature review, the hypothesis was formulated as null hypothesis (Ho) and alternative hypothesis $(\mathrm{Ha})$ as below:

Ho $=$ There was no positive impact of shadowing technique on tertiary EFL learners' achievement in listening skill.

$\mathbf{H a}=$ There was positive impact of shadowing technique on tertiary EFL learners' achievement in listening skill.

\section{Methodology}

\subsection{Participants}

There were 60 students who were involved in this recent study. The students were divided in to two groups named experiment group and control group. Each group consisted 30 students. Moreover, the ranges of their ages were from 17 to 19. The participants were selected randomly from 180 students at English Department, Universitas Negeri Medan, Indonesia. In addition, the students were in the first semester and sitting for Listening 1 subject.

\subsection{Materials}

The Focus on IELTS New Edition book (2010) was selected for this research. This book is written by Sue O'connell and published by Pearson Longman. There are three reasons why this book was considered appropriate for this study. Firstly, the listening material contains different level of the difficulties. Secondly, since the students of English Language and Literature Department Universitas Negeri Medan are expected to be English teachers, the suitable textbook for them is IELTS for academic purpose. Thirdly, the test items in official IELTS test maintained reliability.

\subsection{Procedure}

To carry out this research, the 60 students were divided into two groups with thirty students in each one. One group was the experimental group and the other one was the control group. For the experimental group we had an introductory session before our four-week experiment. In this session, I explained all the seven techniques they could use for shadowing. I asked them to shadow whatever they could get their hands on including listening, reading, speaking, dictionary examples, their partner's speech or anything else at hand. I also mentioned that this was a "fantabulous" technique, confirmed by research that would help if they really were interested in improving their listening skills. No such session was held for the control group. Both of the classes were taught for one month, two sessions a week making eight classes in sum. Both of the groups were taught from the same book. The only difference in the classes was that the experimental group shadowed the listening exercises, some parts of the reading exercises and I checked every session that the learners in the experimental group were also practicing shadowing outside the class. They even sometimes emailed me what they had shadowed. At the end of the one-month, all sixty students were given listening test.

\subsection{Analysis Technique}

To measure the impact of shadowing technique on the students' achievement in listening comprehension skill, an analysis of t-test and ANCOVA in Statistical Package for Social Science (SPSS) was employed to tabulate the 
data (pre and posttest of listening).

\section{Results and Discussion}

For data analysis, the students listening answers' sheets were checked and scored. Then, the raw data was fed into SPSS software for further analysis. To compare the two sets of scores, descriptive statistics and t-test were conducted and the result is shown on the table below.

Table 2. Group statistics of mean of students' listening scores

\begin{tabular}{llllll}
\hline & Group & $\mathrm{N}$ & Mean & Std. Deviation & Std. Error Mean \\
\hline Listening & Control & 30 & 3.05 & .38 & .06927 \\
Achievement & Experiment & 30 & 6.62 & .50 & .09186 \\
\hline
\end{tabular}

As can be seen in table 2, the experimental group had a higher mean in comparison to the ones in the control group (6.62> 3.05), which Standard Deviation is .50 and 0.38 respectively. Thus, this current study, the experimental group surpassed the control group. To see the significant different of both groups, the descriptive statistic of t-test is presented on the following table.

Table 3. Descriptive statistic of t-test

\begin{tabular}{|c|c|c|c|c|c|c|}
\hline & & \multicolumn{2}{|c|}{$\begin{array}{l}\text { Levene's Test for Equality of } \\
\text { Variances }\end{array}$} & \multicolumn{3}{|c|}{ t-test for Equality of Means } \\
\hline & & $\mathrm{F}$ & Sig. & $\mathrm{t}$ & df & $\begin{array}{l}\text { Sig. } \\
\text { (2-tailed) }\end{array}$ \\
\hline Listening & Equal variances assumed & 8.975 & .004 & 3.1000 & 58 & .000 \\
\hline Achievement & Equal variances not assumed & & & 3.1000 & 53.923 & .000 \\
\hline
\end{tabular}

From Table 3, the test was found that Levene's test for equality of variances examined for the present analysis, $(F=8.98, p=.004<.05)$. Owing to this assumption, a $\mathbf{t}$ statistic assuming the variance was computed. Moreover, this test was found to be statistically significant, $t(58)=3.10, p<.05$. The mean of the experimental group was more than double of the control group's mean. The difference is also displayed graphically in figure 1 . This proves that shadowing was an effective technique in enhancing the listening comprehension skills of the participants in the experimental group. This difference is also statistically significant. In other words, the alternative hypothesis that shadowing techniques give positive impact on tertiary EFL learners' listening skill achievement is confirmed.

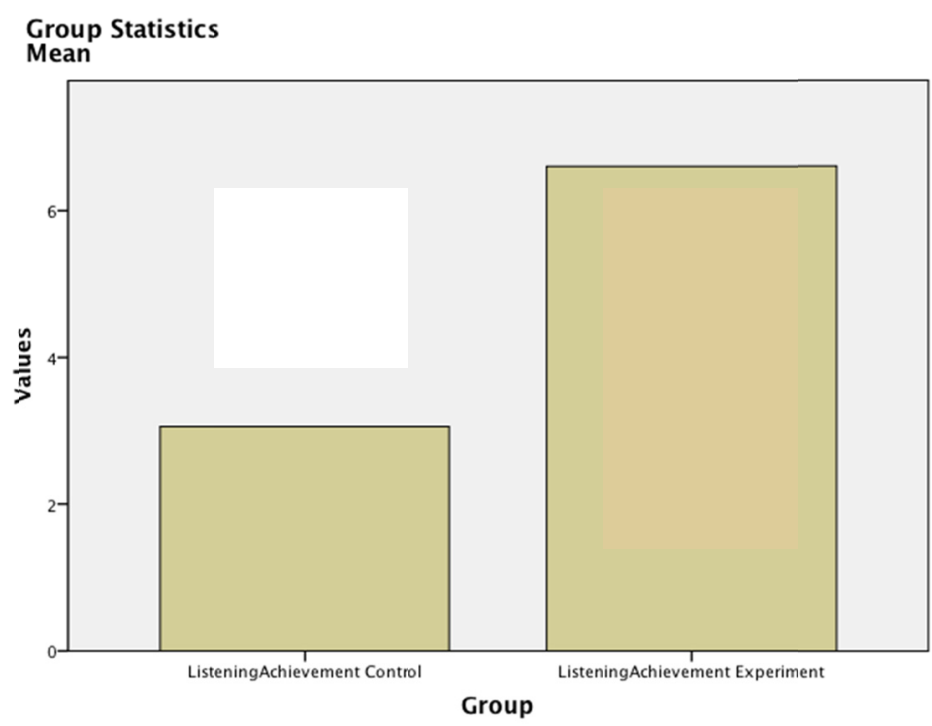

Figure 1. Mean of experimental and control groups 


\subsection{Testing the Null Hypothesis}

In order to test the hypothesis, the ANCOVA was run to examine the effect of the shadowing technique on tertiary ESOL learner' listening skill achievement. The result is presented on the following table.

Table 4. Descriptive statistic of effectiveness

\begin{tabular}{lllllll}
\hline Dependent & Variable: Difference & & & & \\
\hline Source & Type III Sum of Squares & df & Mean Square & F & Sig. & Partial Eta Squared \\
GROUP & 28.02 & 1 & 28.02 & 56.10 & .000 & .49 \\
\hline
\end{tabular}

a. $\mathrm{R}$ Squared $=.49$ (Adjusted R Squared $=.48)$

In spite of the difference prior to the treatment, the effect of the treatment indeed turned out to be statistically significant $(F=56.10, p=0.00<0.05)$. Hence, the null hypothesis of the study, which stated that using shadowing technique had no positive impact on tertiary EFL learners' listening skill achievement was rejected with those receiving the treatment outperforming significantly those in the control group. In other words, the alternative hypothesis of the study, which stated that there is a positive impact of Shadowing technique on tertiary EFL learners' listening skill achievement, was accepted.

\section{Conclusion}

From the result and discussion, it can be concluded that the shadowing technique had a positive impact on the students' achievement in listening skills since there was a significant difference between the mean scores of experimental and control groups. In this study, experimental group outperformed the control group. Furthermore, this technique is suitable to the English as Foreign Language (EFL) learners because the process of acquiring and learning the language is very systematic and contextual. Therefore, this shadowing technique is suggested to be implemented in listening classroom for the better outcomes or students' achievement as especially to the countries, which recognized English as Foreign Language such as Indonesia, Japan, China, and etc.

\section{Implication of the Study}

For the implication of the technique, the teacher needs to inform the EFL learners the fundamental and principle of the shadowing technique to avoid the confusion and misconception of the technique. The learners' motivation and understanding is very important because shadowing technique really employ the learners' cognitive process. Other than that, teacher should inform the function and benefits of shadowing technique. Hopefully, the result of this current study can present new insights into research of shadowing, and then more students will be able to maximize the advantages of shadowing technique.

\section{Limitation of Study}

From this study, there are three kinds of the limitation appeared. Firstly, this study used the same level of material's difficulties. Secondly, although the data show that shadowing technique give a positive impact on the students' achievement in listening skills, the theoretical support for this result should be studied in-depth. This study did not investigate the motivation of the students. Since motivation may also effect the students' achievement in learning second/foreign language. Therefore, further study on the implementation of shadowing technique to many aspects of Teaching English is very recommended.

\section{Acknowledgment}

We thank all the students who participated in this study. We also express our gratitude to the Head of English and Literature Department, Faculty of Art and Language, Universitas Negeri Medan for supporting this research. In addition, many thanks go to Mr. Dedi Sanjaya, M.A. from City University of Kuala Lumpur, Malaysia for his willingness to help this project to reach its successfulness.

\section{References}

Brown, H. D. (2007). Principles of language learning and teaching. NY: Pearson Education.

Ghanbari, F., \& Hashemian, M. (2014). The Effects of English Songs on Young Learners' Listening Comprehension and Pronunciation. International Journal of Language Learning and Applied Linguistics World, 6(3), 337-345.

Hamada, Y. (2011a). A study on a learner-friendly shadowing procedure. Journal of the Japan As- sociation for Developmental Education, 6(1), 71-78. 
Hamada, Y. (2011b). Improvement of listening comprehension skills through shadowing with difficult materials. Journal of Asia TEFL, 8(1), 139-162.

Kadota, S. (2007). Shadowing to ondoku no kagaku [Science of shadowing and oral reading]. Tokyo: Cosmopier.

Murphey, T. (2001). Exploring conversational shadowing. Language Teaching Research, 5(2), 128-155. https://doi.org/10.1191/136216801678766886

O'Connel, S. (2010). Focus on IELTS; New Edition. Edinburg: Pearson Longman.

Onaha, H. (2004). Effect of shadowing and dictation on listening comprehension ability of Japanese EFL learners based on the theory of working memory. JACET Bulletin, 39, 137-148.

Sevik, M. (2012). First step to effective listening: "Listen and show" songs. International Journal of English and Education, 1(1).

Shiki, O., Mori., Y., Kadota, S., \& Yoshida, S. (2010). Exploring differences between shadow- ing and repeating practices. Annual Review of English Language Education in Japan, 21, 81-90.

Someya, Y. (1996). Tsuyaku kunren syuho to sono ippangogaku gakusyu heno ouyou ni tsuite. [A tool for interpreter training technique for language enhancement]. Tsuyaku Rironkenkyu [Interpreting Research], 11.

Suzuki, K. (2007). Shadoing wo moichita Eigo choryoku kojo no shido ni tuite no kensho [Investigation on the instruction for listening comprehension through shadowing]. STEP Bulletin, 19, 112-124.

Takizawa, M. (2002). Gogakukyokaho toshiteno tsuyakukunrenho to sono oyorei [Interpreter training techniques and their application as a tool for language enhancement]. Bulletin of Hokuriku University, 26, 63-72.

Tamai, K. (1992). The effect of "shadowing" on listening comprehension. Unpublished Master's thesis, School of International Training, Brat- tleboro, Vermont.

Tamai, K. (1997). Shadowing no koka to chokai process niokeru ichizuke. [The effectiveness of shadowing and listening process]. Current English Studies, 36, 105-116.

Tamai, K. (2002). On the effects of shadowing on listening comprehension-Keynote lecture at the 3rd Annual Conference of JAIS. Interpretation Studies, 2, 178-192.

Tamai, K. (2005). Listening shidoho to shite no shadowing no koka ni kansuru kenkyu [Research on the effect of shadowing as a listening instruction metho]. Tokyo: Kazama.

Tanaka, M. (2004). Tsuuyaku kunrenhou wo riyou shita eigo kyouikuno jissai to mondai. [Current pedagogical issues in teaching interpreting at undergraduate level]. Interpreting Studies, 4, 63-82.

\section{Copyrights}

Copyright for this article is retained by the author(s), with first publication rights granted to the journal.

This is an open-access article distributed under the terms and conditions of the Creative Commons Attribution license (http://creativecommons.org/licenses/by/4.0/). 